\title{
Kinetics of tidal resuspension of microbiota: testing the effects of sediment cohesiveness and bioturbation using flume experiments
}

\author{
G. F. Blanchard ${ }^{1, *}$, P.-G. Sauriau ${ }^{1}$, V. Cariou-Le Gall ${ }^{1}$, D. Gouleau ${ }^{1}$, \\ M.-J. Garet ${ }^{1}$, F. Olivier ${ }^{2}$ \\ ${ }^{1}$ Centre de Recherche en Ecologie Marine et Aquaculture de L'Houmeau, CNRS-IFREMER, BP 5, \\ F-17137 L'Houmeau, France \\ ${ }^{2}$ Laboratoire maritime de Dinard, Avenue Georges-V, F-35801 Dinard, France
}

\begin{abstract}
Resuspension of the top few sediment layers of tidal mud flats is known to enhance planktonic biomass of microbiota (benthic diatoms and bacteria). This process is mainly controlled by tidal shear stress and cohesiveness of mud, and is also influenced by bioturbation activities. Laboratory experiments in a race track flume were performed to test the interactive effects of these factors on both the critical entrainment and resuspension kinetics of microbiota from silt-clay sediments from the Marennes-Oléron Bay, France. The marıne snail Hydrobıa ulvae was used to mimic surface bioturbation activities. As expected, the kinetics of microblal resuspension versus shear stress were largely controlled by the cohesiveness of silt-clay sediments. However, our results indicate that the cffect of surface tracking by $H$. ulvae on microbial resuspension was clearly dependent on the interaction between sediment cohesiveness and shear velocity. Evidence was also found that microphytobenthos and bacteria are not simultaneously resuspended from silt-clay bioturbated sediments. This supports the theory that diatoms within the easily eroded mucus matrix behave actively and bacteria adhering to fine silt particles eroded at higher critical shear velocities behave passively
\end{abstract}

KEY WORDS: Microphytobenthos - Bacteria - Resuspension - Bioturbation Hydrobia ulvae - Shear velocity - Sediment cohesiveness Flume experiment

\section{INTRODUCTION}

Resuspension of benthic microalgae and bacteria enhances planktonic microbial biomass (Varela \& Penas 1985, Shaffer \& Sullivan 1988, Wainright 1990 de Jonge \& van Beusekom 1992, 1995). For instance the contribution of resuspended microphytobenthos to total phytoplankton can make up about $60 \%$ of the total phytoplankton in the Dollard estuary (de Jonge \& van Beusekom 1992); Baillie \& Welsh (1980) even calculated, in the Branford Harbor estuary, that if only 10 to $15 \%$ of the mudflat sediments were resuspended by tidal currents to a depth of $1 \mathrm{~mm}$ it could account for the chlorophyll levels inside the estuary. It thus

•E-mail: gblancha@ifremer.fr appears that microbial resuspension must be of great importance to the nutrition of zooplankton and filterfeeders (Roman \& Tenore 1978, de Jonge \& van Beusekom 1992), and, more broadly, to the calculation of energy budgets in intertidal mudflats. However, although the importance of microbial resuspension has been demonstrated at the ecosystem level, very little is known about the mechanisms which control it.

Very few studies have so far specifically addressed the issue of microbial resuspension (Wainright 1990 . Denis et al. 1996), and they have restricted themselves to the determination of the critical shear velocity which leads to resuspension of microphytobenthos or bacteria from intact sediments. Such an approach, although very valuable for inter-site comparison purposes, is however inappropriate for a thorough analysis of the biological and physical processes involved in microbial 
resuspension. The full complexity of the benthic microenvironment - including flow characteristics (Nowel \& Jumars 1984), sediment properties (Mehta 1988) and biological activity (Rhoads \& Boyer 1982) - has to be taken into account using an experimental approach which allows for interactions between the different factors to be dealt with. Jumars et al. (1981) have already stressed with the aid of a simple model the importance of flow-sediment-organism interaction on particulate resuspension.

This article aims to explain the effects of shear velocity, sediment cohesiveness, bioturbation and their potential interactions on the resuspension kinetics of microphytobenthos and bacteria under simulated tidal conditions. Flume experiments were designed to simulate a tidal flow (ebb or flood tide) on different unconsolidated sedimentary environments (representative of the mudflat conditions): different levels of sediment cohesiveness were tested with or without an enrichment of macrofauna. The range of sediment cohesiveness that was tested is representative of the readily resuspendable surficial mud in the Bay of MarennesOléron (France). The marine snail Hydrobia ulvae (Pennant) was used to mimic bioturbation activity in the experiments, not only because it is one of the most abundant macrofauna species in European estuaries and sheltered muddy shores (Reise 1985), but also because its various bioturbation behaviors are well described (see e.g. Barnes 1981). Besides the effect of each factor on microbial resuspension, one particular issue that we addressed in these experiments is how a change of the sediment properties affects bioturbation. and what the consequences are for microbial resuspension.

\section{MATERIAL AND METHODS}

The experimental flume. Experiments were performed using the laboratory flume 'HYCOBENTHOS' (HYdrodynamisme et COmportement du BENTHOS) at 'Laboratoire maritime de Dinard', France. The flume has a race track shape and has a total length of $13 \mathrm{~m}$, a cross section of $0.5 \mathrm{~m}$ and a depth of $0.3 \mathrm{~m}$. The flume is composed of an experimental section, where the sediment is introduced and then eroded, and, on the opposite side, a driving section which generates the fluid movement. The latter section is made of 14 disks (80 $\mathrm{cm}$ diameter, $5 \mathrm{~mm}$ thickness) rotating around a horizontal axis so that seawater is moved by friction; the speed of the generated current is a function of the angular speed of the disks (see Champalbert \& Marchand 1994, de Montaudouin \& Bachelet 1996 for more details). The working section located along the $3.5 \mathrm{~m}$ long straight line opposite the wheel is $0.4 \mathrm{~m}^{2}(1 \mathrm{~m}$ length, $0.4 \mathrm{~m}$ wide): the width is smaller than the flume's cross section to prevent wall effects. These characteristics of the flume allow the simulation of benthic environments according to Nowell \& Jumars' (1987) theoretical and experimental considerations. The flume was filled with seawater which had been pumped from the neighbouring bay a few hours before the experiments and which had been filtered through $1 \mu \mathrm{m}$ filters to remove phytoplankton. The water height within the flume was $20 \mathrm{~cm}$. A series of preliminary experiments had previously been performed in order to determine the optimal operating conditions of the flume.

Characteristics of the generated flow. Typically, tidal current velocities at $15 \mathrm{~cm}$ above the intertidal flat in Marennes-Oléron Bay are in the range 5 to $50 \mathrm{~cm} \mathrm{~s}^{-1}$ (Raillard et al. 1994). Velocity profiles in the race track flume were obtained with an ultrasonic current meter (Minilab model SD-12, Sensor Data, Bergen, Norway) and determined for a range of free stream velocities similar to those found in the field: $5.5 \pm 0.2$ to $48.9 \pm$ $2.1 \mathrm{~cm} \mathrm{~s}^{-1}$ (mean $\pm \mathrm{SD}$ ) at $15 \mathrm{~cm}$ above the bottom. Shear velocities $\left(u ., \mathrm{cm} \mathrm{s}^{-1}\right)$ were calculated from the logarithmic section of the corresponding velocity profiles according to Nowell et al. (1981) and ranged from $0.32 \pm 0.01$ to $2.62 \pm 0.05 \mathrm{~cm} \mathrm{~s}^{-1}$ (mean $\pm \mathrm{SD}$ )

Physical characteristics of the sediment. The sediment used for the experiments came from Brouage mudflat in the eastern part of Marennes-Oléron Bay (see Sauriau et al. 1989 for a detailed sedimentary map). Only the top $\mathrm{cm}$ of the sediment was used. This was a silty sediment with $98 \%$ of particles $<50 \mu \mathrm{m}$ and a mean size averaging 4 to $6 \mu \mathrm{m}$ as determined by laser diffraction method (Bassoulet unpubl.). Rheological properties of pure cohesive sediments (i.e. cohesiveness) depend mainly on their concentration (Migniot 1968), and an empirical relationship can be established between the concentration of the sediment ( $T s, \mathrm{~g} \mathrm{l}^{-1}$ ) and the yield value $\left(\tau_{y}, \mathrm{~N} \mathrm{~m}^{-2}\right)$. Parameters of the power law $\left(\tau_{\mathrm{y}}=4.7 \times 10^{-7} \mathrm{Ts}^{2.89}, \mathrm{n}=92, \mathrm{R}^{2}=0.86\right)$ were determined with a Brookfield LTVD viscometer for a rotor speed of 0.3 rev $\mathrm{min}^{-1}$.

In order to evaluate the variations in silty sediment entrainment due to biological activity under different rheological conditions, experiments were carried out using 3 different sediment concentrations (181 \pm 6 . $212 \pm 2$ and $252 \pm 1 \mathrm{~g} \mathrm{l}^{-1}$ ) (mean $\pm \mathrm{SD}$ ) corresponding to the 3 following yield values: 1.60, 2.40 and $4.10 \mathrm{~N} \mathrm{~m}^{-2}$. This range is representative of pure mud found in the field. The highest cohesiveness corresponds to the sediment that was sampled. The lower levels of cohesiveness were obtained by diluting the sediment with seawater from the sampling site.

Faunal enrichment. The gastropod Hydrobia ulvae is a surface deposit-feeder of which adult densities 
average more than 3000 ind. $\mathrm{m}^{-2}$ at an upper mudflat level of 3 to $5 \mathrm{~m}$ above the extreme low spring-tide level in Marennes-Oléron Bay. For the experiment with faunal enrichment, we added $10^{4}$ ind $\mathrm{m}^{-2}$ of which the size range was 4 to $6 \mathrm{~mm}$. This density is close to the highest levels of $H$. ulvae adults recorded in the bay (Sauriau 1987). Individuals of H. ulvae were gently spread at the surface of the sediment in the working section and were left to crawl and bury themselves during filling of the flume ( $2 \mathrm{~h}$ period).

Experimental design and ANOVA analysis. The experiments were organized according to a partiallyhierarchical design with 3 fixed factors: sediment cohesiveness ( 3 levels); density of Hydrobia ulvae (with and without faunal enrichment); and shear velocity. The first 2 factors, $H$. ulvae density and sediment cohesiveness, were fully crossed and organized as a 2 -way design with replications. Two replications of this complete $3 \times 2$ factorial experiment were conducted in a random sequence of 12 flume experiments. Within each flume experiment, the current velocity was increased step by step (12 shear velocity levels ranging from 0.32 to $2.62 \mathrm{~cm} \mathrm{~s}^{-1}$ ). The shear velocity factor was therefore nested within the flume experiment factor.

This partially-hierarchical design (see Brownlee 1965 for a detailed definition) can be compared to a split-plot design (Potvin 1993) which involved 2 between-flume-experiment crossed-factors and a within-flume-experiment factor The unit of comparison for H. ulvae density and sediment cohesiveness factors was 1 flume experiment, while different shear velocities were applied within each flume experiment. Each flume experiment is random assuming that the main factors $H$. ulvae density and sediment cohesiveness have to be tested over the flume experiment variability (Table 1). The response variables were logtransformed in order to fit ANOVA assumptions (Sokal \& Rohlf 1981). The ANOVA analysis was performed using the MINITAB package, release 10

Sampling. For each flume experiment and at each velocity step, the current velocity was maintained for a 20 min period in order to reach a steady state of suspended sediment concentration. This value was determined during the first set of resuspension experiments and is consistent with the time-step used by other laboratory erosion studies (Davis 1993, Denis et al. 1996). Just before increasing the velocity, water was sampled for measuring chl a concentration (used as an index of microalgal biomass) and counting bacteria. Three $100 \mathrm{ml}$ water samples were drawn downstream from the experimental section (at the surface, at mid-depth, and just above the bottom) for chl a measurements using the fluorometric method (Lorenzen 1966). Only 1 sample (mid-depth) was used for bacteria counting. Total bacterial abundances were determined in sub- samples filtered through black $0.2 \mu \mathrm{m}$ Nuclepore filters after staining with $5 \mathrm{\mu g} \mathrm{ml}^{-1}$ acridine orange (Hobbie et al. 1977, Meyer-Reil 1977). To dislodge bacteria, we diluted the fixed mud samples with tetrasodium pyrophosphate $\left(\mathrm{Na}_{2} \mathrm{P}_{2} \mathrm{O}_{7}, 0.01 \mathrm{M}\right.$ final concentration) and sonicated them with a Sonimasse 520 equiped with a miniprobe at $40 \%$ of maximum power for $30 \mathrm{~s}$ (Velji \& Albright 1986, 1993) At least 200 cells were enumerated in 10 to 20 fields per sample at $1250 \times$ magnification using an epifluorescence microscope.

\section{RESULTS AND DISCUSSION}

\section{Kinetics of microbial resuspension}

The cumulative response curves of microphytobenthos and bacteria resuspension are presented in Figs. 1 \& 2 ; the curves account for the initiation and the dynamics of microbial resuspension (up to the mass resuspension of sediment; afterwards the process is limited by the availability of sediment in the working area of the flume) when the sediment-water interface is experimentally subjected to a simulated tidal erosion. A logarithmic scale on the $y$-axis is used to detect the early stages of resuspension by emphasizing changes in the lower range of chl a concentration or bacterial density scales.

Partially-hierarchical 3-way ANOVAs, performed on log-transformed chl a and bacterial concentrations, clearly show that the 2 main effects (bioturbation and sediment cohesiveness) are statistically significant on both microalgal and bacterial resuspension (Table 1). The interaction between bioturbation and sediment cohesiveness is not significant, but the interaction between bioturbation, sediment cohesiveness and shear velocity is significant $(p=0.019$ and $p=0.012$ for microalgae and bacteria, respectively; Table 1). This indicates that the effects of bioturbation, sediment cohesiveness and of their interactions have to be analysed in the context of the resuspension kinetics because they change during the course of the simulated tidal erosion.

The significant effect of sediment cohesiveness on both microalgal $(p<0.001)$ and bacterial $(p<0.001)$ resuspension (Table 1 ) is evident from Figs. $1 \& 2$ : the steepness of the curves as well as the duration of the resuspension process decreases as sediment cohesiveness increases. The general pattern is clearly a mass resuspension occurring at the critical shear velocity $(u \cdot c)$ in the case of the least cohesive sediment $\left(\tau_{y}=\right.$ $1.6 \mathrm{~N} \mathrm{~m}^{-2}$ ), a more gradual resuspension process for the intermediate cohesiveness $\left(\tau_{y}=2.4 \mathrm{~N} \mathrm{~m}^{-2}\right)$, and a strong resistance to erosion for the most cohesive sediment $\left(\tau_{y}=4.1 \mathrm{~N} \mathrm{~m}^{-2}\right)$ which limits microbial resuspen- 

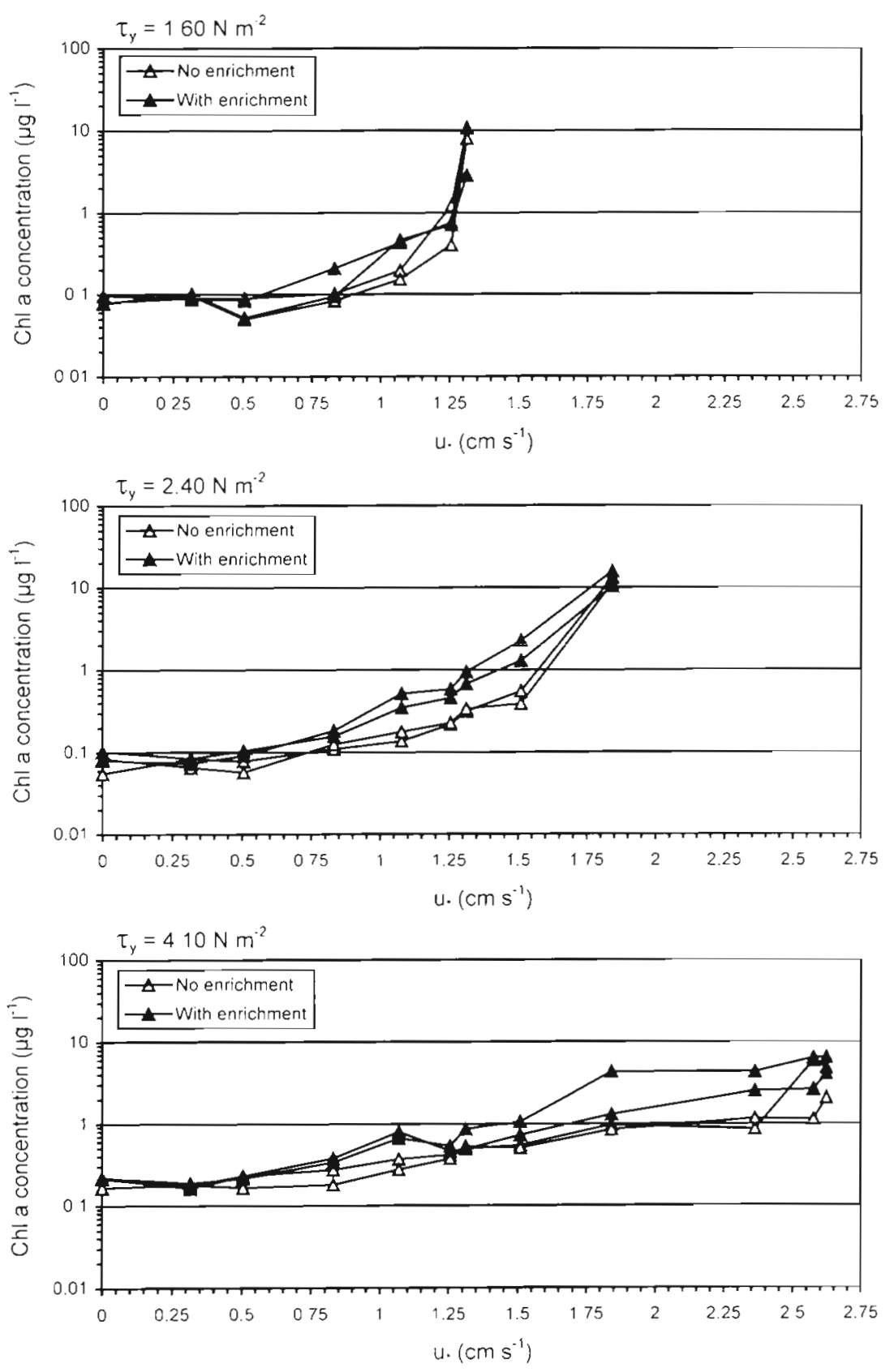

Fig. 1. Cumulative response curve of microphytobenthos resuspension. The cumulative chl a concentration is plotted against the shear velocity $(u \cdot)$ for 3 different cohesiveness values $\left(\tau_{y}\right) .(\Delta)$ Duplicated experiments without macrofaunal enrichment; $_{(\Delta)}$ duplicated experiments with addition of Hydrobia ulvae. Because the kinetıcs of resuspension differed as a function of sediment cohesiveness, the maximum chl a resuspension (of the order of $10 \mu \mathrm{g} \mathrm{l}^{-1}$ ) was not achieved at the same shear velocity

sion. Thus, the enhancement of microbial biomass in the water column by tidal currents is strongly controlled by the sediment cohesiveness: the more cohesive the sediment, the higher the shear velocity for tidal current above the sea bed) has to be to resuspend an equal quantity of cells.
The significant bioturbation effect due to Hydrobia ulvae ( $\mathrm{p}=0.009$ and $\mathrm{p}=0.004$ for microalgae and bacteria, respectively; Table 1 ) is also pointed out in Figs. 1 \& 2: the intensity of the effect, however, changes as a function of both the sediment cohesiveness and the shear velocity (due to the significant interaction between bioturbation, sediment cohesiveness and shear velocity]. Therefore, in order to point out and to analyse this additional biological effect (it is also a cumulative effect), we express it as a percentage of the physical effect (see legend of Fig. 3 for details of the calculation) and plot it in Fig. 3 as a function of the shear velocity for the 3 different sediment cohesiveness values. It is then clear that the enhancement effect due to bioturbation is restricted to a narrow range of shear velocities in the case of the least cohesive sediment: up to $155 \%$ at $1.08 \mathrm{~cm}$ $\mathrm{s}^{-1}$, then no effect from $1.26 \mathrm{~cm} \mathrm{~s}^{-1}$ onwards, for microalgae (Fig. 3A), and almost negligible effect for bacteria from the lowest shear velocity onwards (less than 10\%; Fig. 3B). The bioturbation effect greatly increases resuspension for the intermediate cohesiveness (up to ca 300\% for microalgae and ca $100 \%$ for bacteria) and is active for a larger range of intermediate shear velocities up to $1.51 \mathrm{~cm}$ $\mathrm{s}^{-1}$ for both microalgae and bacteria. Then, at $1.84 \mathrm{~cm} \mathrm{~s}^{-1}$ the biological effect drops dramatically (down to ca $10 \%$ ). Finally, at the highest sediment cohesiveness, the biological effect seems to be active over the full range of shear velocities which were tested, and reached enhancement levels of resuspension of about $240 \%$ and $120 \%$ for microalgae and bacteria, respectively.

It turns out that the biological effect occurs at the start of resuspension, and it appears to be all the more effective, in terms of shear velocity range (hence intensity since it is a cumulative effect), when the sediment cohesiveness is higher (within the experimental conditions): in other words, the enhancement of microbial resuspension by Hydrobia ulvae is clearly medialed by the interaction between the sediment cohesiveness 
and the shear velocity $(p<0.001$ for both microalgae and bacteria; Table 1). If we further extrapolate this interaction to actual field conditions during high tide on an intertidal mudflat, the enhancement of microbial resuspension by $H$. ulvae should be effective only within a temporal window (defined by the range of shear velocity within which $H$. ulvae is effective), the duration of this window being directly dependent on the sediment cohesiveness (Fig. 3). As a result, it is evident that the observation of this interaction opens new perspectives for ecophysiological studies concerning filter-feeder nutrition.

\section{Determination of the critical shear velocity}

A more classical approach in erosion studies is to determine the critical shear velocity of resuspended particles. There are however no easy and precise means of determining it in such mesocosms. It is usually achieved by visual observation for sediment resuspension, but the method may be subjective (Nowell et al. 1981) and is inappropriate for microbiota. So, we based its determination on a graphical examination (from Figs. 1 \& 2). We then compared the results obtained by this approach with the visual observations which had been recorded during the flume experiments (i.e. critical shear velocity inducing initiation of mucus and silt motion). Results reported in Fig. 4A are in good agreement with the values of $u$.c published in the literature for microphytobenthos (for instance 0.75 to $1 \mathrm{~cm} \mathrm{~s}^{-1}$; Denis et al. 1996), but are slightly higher than those recorded for bacteria $\left(0.95\right.$ to $1.35 \mathrm{~cm} \mathrm{~s}^{-1}$; Wainright 1990). However, in the latter case the sediment was sandy, making it difficult to compare the values of $u$. .

Two-way ANOVAs show that the sediment cohesiveness significantly increases $u$. for bacteria $(p<0.001)$ and significantly affects microphytobenthos (but no general trend of increase;
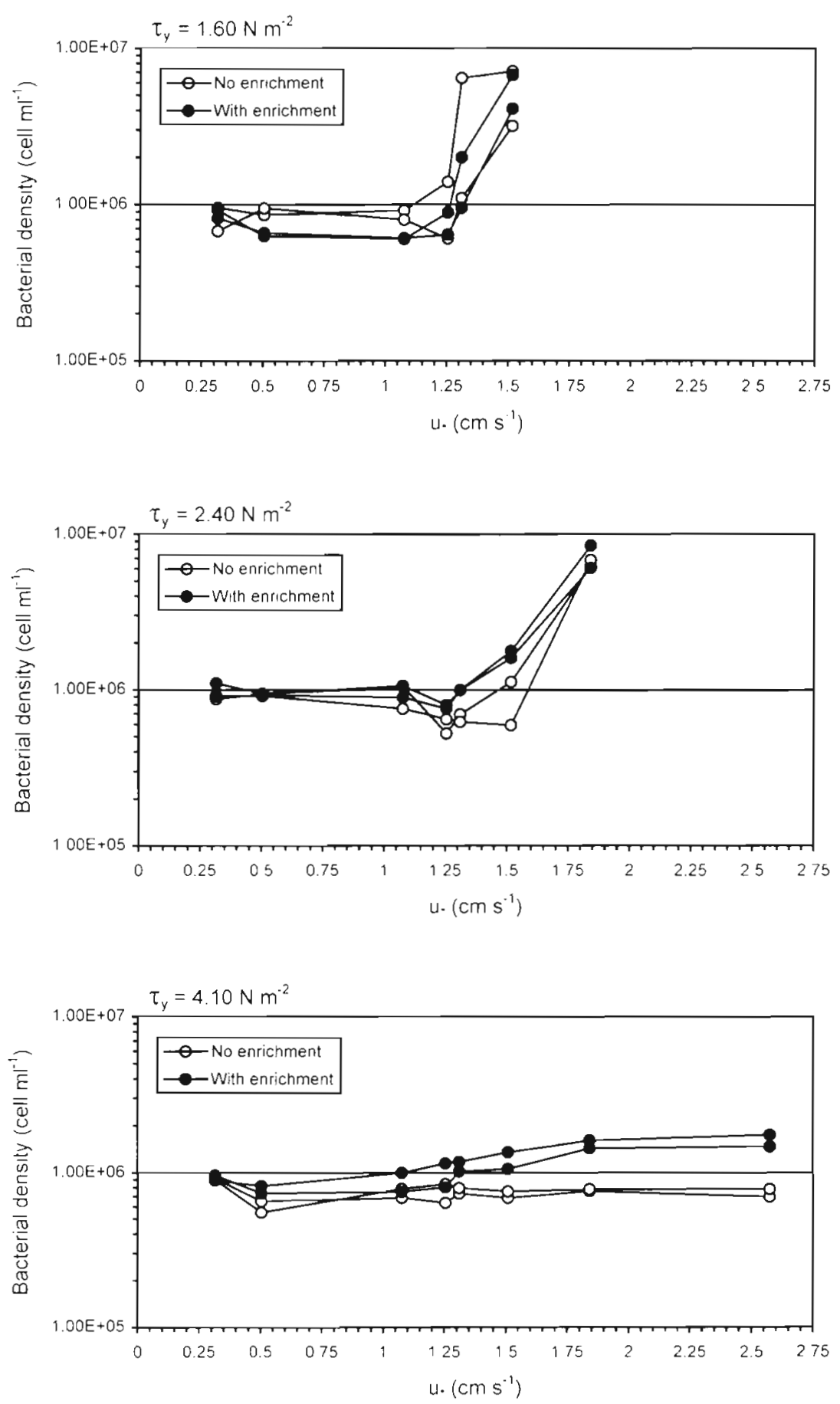

Fig. 2. Cumulative response curve of bacterial resuspension. The cumulative bacterial density is plotted against the shear velocity $(u$.$) for 3$ different cohesiveness values $\left(\tau_{y}\right)$. (O) Duplicated experments without macrofaunal enrichment; ( duplicated experiments with addition of Hydrobia ulvae. Because the kinetics of resuspension differed as a function of sediment cohesiveness, the maximum bacterial cell resuspension (of the order of $1 \times 10^{7}$ cells $\mathrm{I}^{-1}$ ) was not achieved at the same shear velocity. In contrast to microphytobenthos, bacteria were not counted at every shear velocity tested; however, this does not affect our results for the kinetics of resuspension or the determination of the critical shear velocity (the latter is determined with the same precision as for microphytobenthos) 
Table 1. Partially-herarchical 3-way ANOVA on log-transformed chl a and bacterial concentrations. The flume experiment factor is random assuming that the main factors Bioturbation and Cohesiveness have to be tested over the flume experiment variability

\begin{tabular}{|c|c|c|c|c|c|}
\hline Source of variation & df & SS & MS & $F$ & $\mathrm{p}$ \\
\hline \multicolumn{6}{|l|}{ Chl a $\left(\log \mu \mathrm{g}^{-1}\right)$} \\
\hline Bioturbation & 1 & 1.093 & 1.093 & 14.60 & 0009 \\
\hline Cohesiveness & 2 & 10.194 & 5.097 & 68.04 & $<0.001$ \\
\hline Bioturbation $\times$ Cohesiveness & 2 & 0.049 & 0.025 & 0.33 & 0.729 \\
\hline Flume run (bioturbation cohesiveness) & 6 & 0.449 & 0.074 & 4.89 & $<0.001$ \\
\hline Shear velocity & 11 & 95.744 & 8.704 & 568.51 & $<0.001$ \\
\hline Bioturbation $\times$ Shear velocity & 11 & 0.288 & 0.026 & 1.71 & 0.089 \\
\hline Cohesiveness $\times$ Shear velocity & 22 & 13.817 & 0.628 & 41.02 & $<0.001$ \\
\hline Bioturbation $\times$ Cohesiveness $\times$ Shear velocity & 22 & 0.661 & 0.030 & 1.96 & 0.019 \\
\hline Error & 66 & 1.010 & 0.015 & & \\
\hline Total & 143 & 123.309 & & & \\
\hline \multicolumn{6}{|l|}{ Bacteria $\left(\log\right.$ cell $\mathrm{ml}^{-1}$ ) } \\
\hline Bioturbation & 1 & 0.400 & 0.400 & 21.07 & 0.004 \\
\hline Cohesiveness & 2 & 2.114 & 1.057 & 55.64 & $<0.001$ \\
\hline Bioturbation $\times$ Cohesiveness & 2 & 0.025 & 0.012 & 0.67 & 0.545 \\
\hline Flume run (bloturbation cohesiveness) & 6 & 0.113 & 0.019 & 3.36 & 0.008 \\
\hline Shear velocity & 8 & 16.121 & 2.015 & 355.94 & $<0.001$ \\
\hline Bioturbation $\times$ Shear velocity & 8 & 0.289 & 0.036 & 6.39 & $<0.001$ \\
\hline Cohesiveness $\times$ Shear velocity & 16 & 3.576 & 0.223 & 39.48 & $<0.001$ \\
\hline Bioturbation $\times$ Cohesiveness $\times$ Shear velocity & 16 & 0.212 & 0.013 & 2.35 & 0.012 \\
\hline Error & 48 & 0.271 & 0.005 & & \\
\hline Total & 107 & 23.125 & & & \\
\hline
\end{tabular}

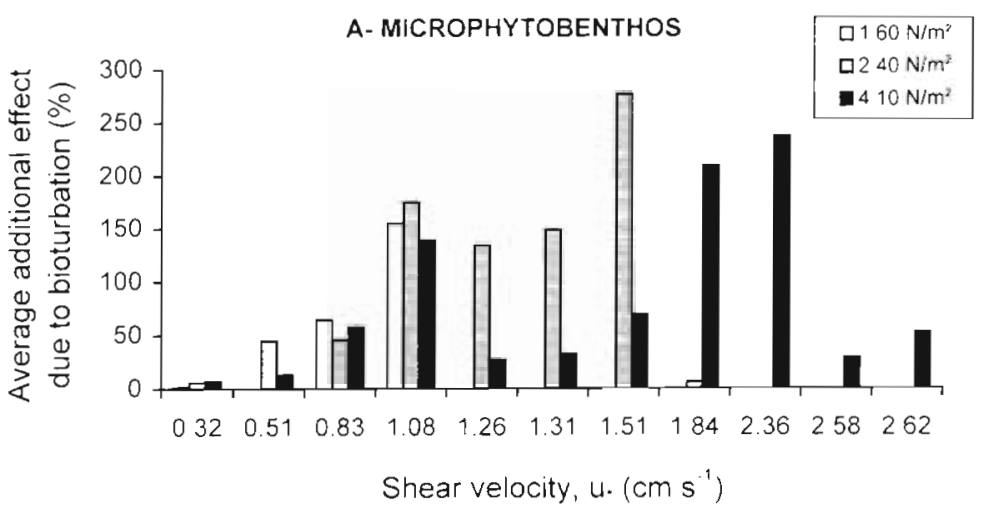

B- BACTERIA

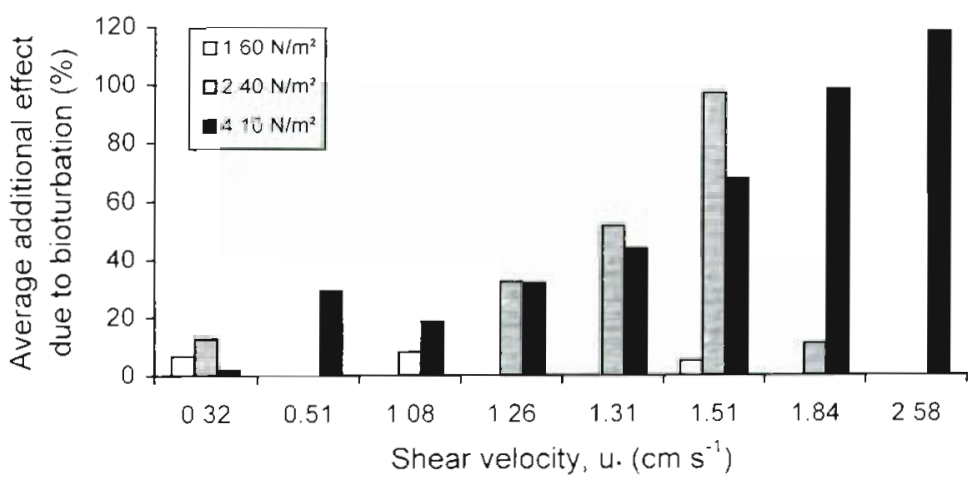

$\mathrm{p}=0.002$ ), and that bioturbation significantly decreases $u_{\cdot c}$ for both bacteria $(p=$ $0.002)$ and microphytobenthos $(p=0.05)$. However, $u \cdot c$ for bacteria is ultimately controlled by the interaction between sediment cohesiveness and bioturbation ( $p=$ 0.002; Fig. 4A): the decreasing effect of bioturbation on $u_{\cdot c}$ is all the more important when the sediment cohesiveness is higher. This interaction term is, however, not significant for microphytobenthos $(\mathrm{p}=$ 0.269 ), thus suggesting that the decreasing effect of bioturbation on $u . c$ is not dependent on the sediment cohesiveness.

The increase of $u \cdot{ }_{c}$ for bacteria due to sediment cohesiveness is consistent with what can be predicted from the relationship between $u \cdot c$ and the sediment co-

Fig. 3. Enhanced microbial resuspension due to bioturbation by Hydrobia ulvae for the 3 levels of sediment cohesiveness (average yield value. $\tau_{\mathrm{r},} \mathrm{N} \mathrm{m}^{-2}$ ). Calculation is based on cumulative response curves of Figs. 1 \& 2. Additional cumulative effect due to bioturbation $(\%)=[(X$ with enrichment $-X$ no enrichment $) / X$ no enrichment $\times 100$. (A): $X=$ chl a concentration, (B): $X$ = bacterial density 
hesiveness of unconsolidated sediments (Migniot 1968): there is a proportional increase of $u \cdot c$ as a function of sediment cohesiveness. In addition, the effect of bioturbation is also consistent with the results of Nowell et al. (1981), who showed that tracking by animals increases the boundary roughness and decreases the erosion threshold. In the specific case of Hydrobia ulvae, the presence of shells at the sediment-water interface also increases the rugosity, and furthermore this gastropod secretes mucus at the surface of the sediment. The visual observations made during the experiments indicate that this mucus was eroded and suspended together with agglomerated sediment before the free sediment surface was eroded itself It is then worth noting that, in many cases, the resuspension of these mucus-sediment agglomerates occurred at the $u_{\text {.c }}$ values as those for microbiota resuspension in the experiments with faunal enrichment (Fig. 4B). As a result, secretion of the mucus by $H$. ulvae with a further agglomeration of the sediment surface (together with microbes inhabiting it) might explain why the critical shear velocity is decreased in the presence of $H$. ulvae. However, this is the first report of an interaction between sediment cohesiveness and bioturbation on bacterial resuspension

Finally, paired comparisons based on a t-test (Sokal \& Rohlf 1981) indicate that pooled values of $u$.c are different between bacteria and microalgae (2-tailed test, $p<0.001)$. In addition, microalgae exhibited lower $u . c$ than bacteria in every case (Fig. 4A; 1 -tailed test, $p<0.001$ ), thus suggesting a highly significant differential resuspension of microbial communities. During tidal resuspension when the current velocity increases, microalgae appear to be resuspended first, followed by bacteria. This difference between the critical erosion velocity of microalgae and bacteria is further significantly affected by the interaction between sediment cohesiveness and bioturbation ( 2 -way ANOVA, $p<0.001$ ): the difference (hence the

\section{A- MICROBIOTA}

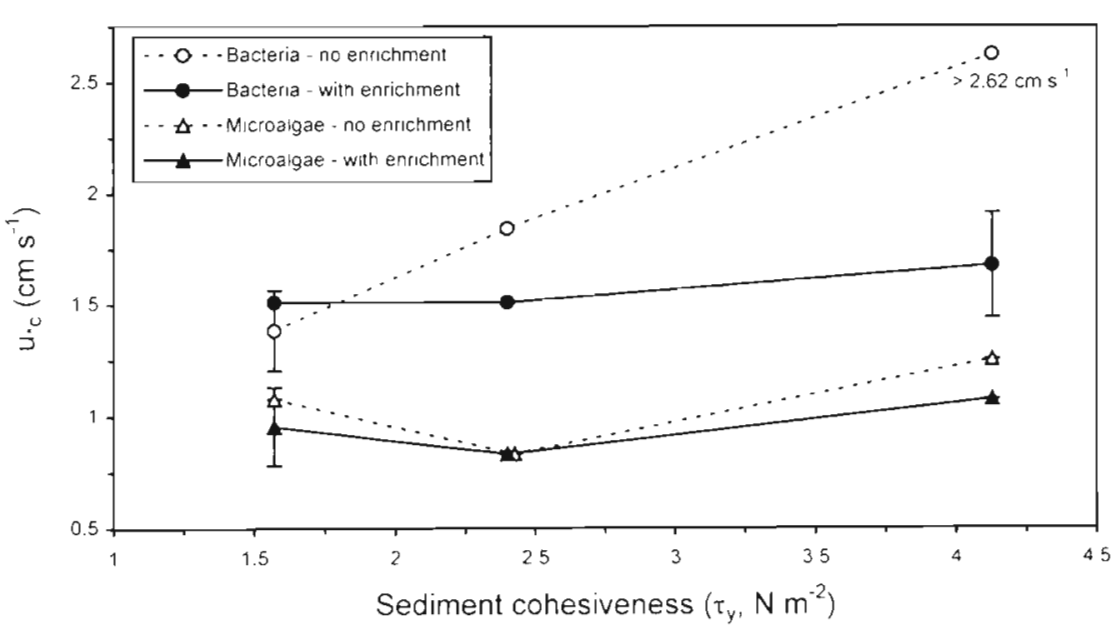

B- MUCUS AND SEDIMENT

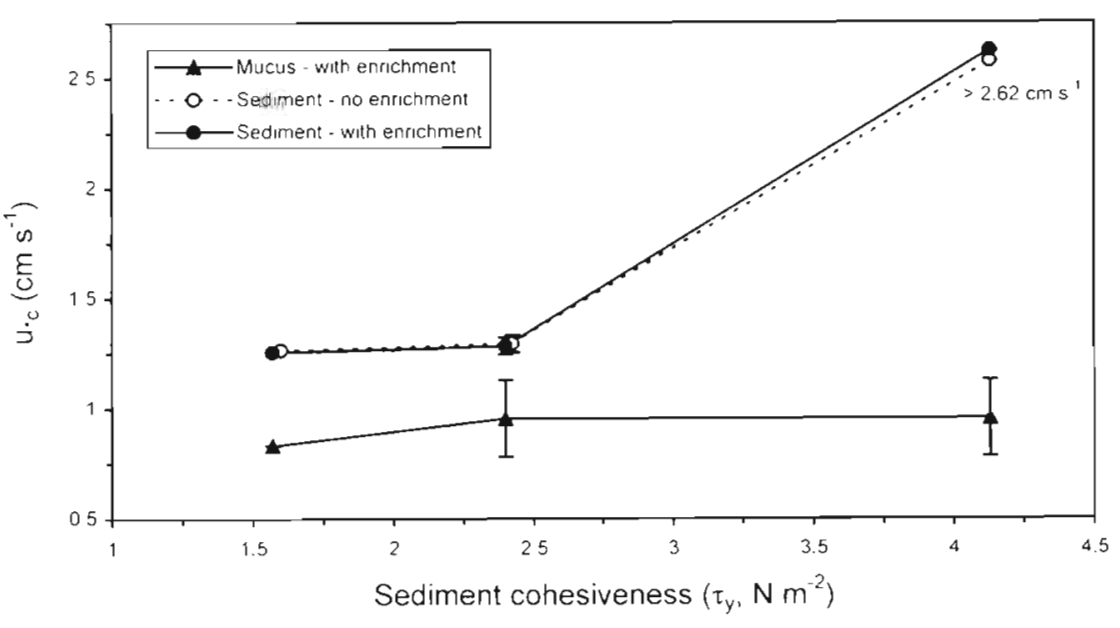

Fig. 4. Critical shear velocity $(u \cdot c)$ as a function of sediment cohesiveness $\left(\tau_{y}\right)$ and bioturbation effect (with and without addition of Hydrobia ulvae). (A) $u \cdot c$ for microalgae and bacteria, determined from Figs. 1 \& 2 . (B) $u_{\bullet}$ for mucus and sediment, determined by visual observation of the sediment surface during the experiments; there is only 1 dataset of $u{ }_{{ }_{c}}$ for the mucus since 1 t does not exist when there

is no addition of macrofauna on the sediment (the 'no enrichment' treatment) time lag) between $u \cdot c$ for bacteria and microalgae is all the more increased by bioturbation when the sediment cohesiveness is higher (note also that the sediment cohesiveness increases this difference, $p=0.003$ ). Besides, if we compare the effect of Hydrobia ulvae on the overall kinetics of microalgal and bacterial resuspensions, it appears that the enhancement of resuspension was relatively more important for microalgae (Fig. 3, maximum enhancement of about $300 \%$ vs $120 \%$ for bacteria). This is the first report of such a difference between resuspension thresholds of microalgae and bacteria. 


\section{Hypotheses on the early resuspension of microphytobenthos}

This observed difference in resuspension might firstly be explained by a behavioral difference: intertidal benthic microalgae are generally composed of motile diatoms (this was the case with the experimental sediment, Cariou-Le Gall \& Blanchard 1995), while bacteria are mainly attached to sediment particles. In field conditions, the motility of microalgae is controlled by an endogenous rhythm (Aleem 1950, Callame \& Debyser 1954, Palmer \& Round 1967, Round 1979, Paterson 1989, Paterson et al. 1990) so that they migrate upwards to the top of the sediment surface during low tide. In the conditions which prevailed in our flume experiments (mixed sediment not subjected to tidal influences for several days), microalgae were very likely no longer controlled by the endogenous rhythm, but they could nevertheless have migrated upwards to the surface mud to seek light for photosynthesis. In doing so, they would have accumulated at the sediment surface (while bacteria would not have), where they would be more likely to be resuspended or to be trapped in the mucus secreted by Hydrobia ulvae, and then eroded. This hypothesis is supported by our visual observation of sediment and mucus motion during the experiments (Fig. 4B): mucus is always resuspended at lower shear velocites than sediment. Moreover, in terms of critical shear velocities (Fig. 4A, B), the resuspension pattern of mucus is very similar to that of microalgae while the resuspension threshold pattern of bacteria is very similar to that of the sediment. Finally, the hypothesis of the diatom-enriched mucus is further supported by observations of a previous study showing that freshly produced trails of another gastropod (Monodonta turbinata) are almost free of bacteria (Herndl \& Peduzzi 1989).

An alternative hypothesis is that the trophic behavior of Hydrobia ulvae might have influenced microbial resuspension because of feeding preference on bacteria. Duration of experiments was indeed consistent with the time span needed by $H$. ulvae to fill its gut (i.e. 30 to $4.0 \mathrm{~min}$ according to Fenchel et al. 1975). However, there is increasing evidence that microalgae, instead of bacteria, represent the primary food source of this species (Jensen \& Siegismund 1980, Morrisey 1988 and references cited therein).

Several conclusions may be drawn from this study. (1) The kinetics of microbial resuspension clearly shows that the critical shear velocity is not a sufficient indicator of erosion processes in that it does not depend on resuspension rates above the critical threshold. This opinion is in agreement with that of Grant \& Daborn (1994) who insist on the decoupling of erosion rate and threshold. (2) The cohesiveness of the sedi- ment has a large impact on the kinetics of microbial resuspension and on the critical erosion threshold therefore, studies dealing with resuspension must report the value of the sediment cohesiveness. (3) The enhancement effect of Hydrobia ulvae on microbial resuspension is controlled by the interaction between the sediment cohesiveness and the shear velocity. (4) There is a differential resuspension among the different microbial communities

Acknowledgements. We are greatly indebted to C. Rétière Drector of the Dinard Marine Laboratory (MNHN), for hav ing provided us with extensive research facilities. We are also very grateful to Dr P. Gros, who helped us with the statıstical analyses. This work was supported by CNRS and IFREMER funds. V.C.L.G. was supported by a MERS research studentship. This study is within the framework of the European Community program INTRMUD (contract no. MAS3-CT950022)

\section{LITERATURE CJTED}

Aleem AA (1950) The diatom community inhabiting the mudflats at Whitstable. New Phytol 47:174-188

Baillie PW, Welsh BL (1980) The effect of tidal resuspension on the distribution of intertidal epipelic algae in an estuary. Estuar Coast Shelf Sci 10:165-180

Barnes RSK (1.981) Behavioural activities and ecological strategies in the intertidal gastropod Hydrobia ulvae In: Jones NV, Wolff WJ (eds) Feeding and survival strategies of estuarine organisms. Plenum Publishing Corp, New York, p 79-90

Brownlee KA (1965) Statistical theory and methodology in science and engineering. J Wiley \& Sons, New York

Callame B, Debyser J (1954) Observations sur les mouvements des diatomées à la surface des sédiments marins de la zone intercotidale. Vie Milieu 5:243-249

Carou-Le Gall V, Blanchard GF (1995) Monthly HPLC measurements of pigment concentration from an intertidal muddy sediment of Marennes-Oléron Bay, France. Mar Ecol Prog Ser 121:171-179

Champalbert G. Marchand J (1994) Rheotaxis in larvae and juveniles sole (Solea solea L.): influence of I.ght conditions and sediment J Exp Mar Biol Ecol 177:235-249

Davis WR (1993) The role of bioturbation in sedıment resuspension and its interaction with physical shearing. J Exp Mar Biol Ecol 171:187-200

de Jonge VN, van Beusekom JEE (1992) Contribution of resuspended microphytobenthos to total phytoplankton in the Ems estuary and its possible role for yrazers. Neth J Sea Res 30:91-105

de Jonge VN, van Beusekom JEE (1995) Wind- and tideinduced resuspension of sediment and microphytobenthos from tidal flats in the Ems estuary. Limnol Oceanogr 40: $766-778$

de Montaudouin X, Bachelet $G$ (1996) Experimental evidence of complex interactions between biotic and abiotic factors in the dynamics of an intertidal population of the bivalve Cerastoderma edule. Oceanol Acta 19:449-463

Denis L, Grenz C, Plante-Cuny MR (1996) Etude experimentale de la remise en suspension du microphytobenthos. Cr Acad Scl Paris, Sér III 319:529-535

Fenchel T, Kofoed LH, Lappalainen A (1975) Particle-size selection of two deposit feeders: the amphipod Corophium 
volutator and the prosobranch Hydrobia ulvae. Mar Biol 30:119-128

Grant J, Daborn G (1994) The effect of bioturbation on sediment transport on an intertidal mudflat. Neth J Sea Res 32 $63-72$

Herndl GJ, Peduzzi P (1989) Potential microbial utilization rates of sublittoral gastropod mucus trails. Limnol Oceanogr 34:780-784

Hobbie JE, Daley RJ, Jasper S (1977) Use of nuclepore filters for counting bacteria by fluorescence microscopy. Appl Environ Microbio] 33:1225-1228

Jensen KT, Siegismund HR (1980) The importance of diatoms and bacteria in the diet of Hydrobia ulvae. Ophelia 17 193-199

Jumars PA, Nowell ARM, Self RFL (1981) A simple model of flow-sediment-organism interaction. Mar Geol 42:155-172

Lorenzen CJ (1966) A method for the continuous measurement of in vivo chlorophyll concentration. Deep Sea Res 13:223-227

Mehta AJ (1988) Laboratory studies on cohesive sediment deposition and erosion. In: Dronkers J, van Leussen $\mathrm{V}$ (eds) Physical processes in estuaries. Springer-Verlag. Berlin, p 427-445

Meyer-Reil LA (1977) Bacterial growth rates and biomass production. In: Rheinheimer G (ed) Microbial ecology of a brackish water environment. Springer-Verlag, Berlin, p 223-235

Migniot C (1968) Etude des propriétés physiques de différents sédiments très fins et de leur comportement sous des actions hydrodynamiques. Houille Blanche 7 : $591-620$

Morrisey DJ (1988) Differences in effects of grazing by deposit-feeders Hydrobia ulvae (Pennant) (Gastropoda: Prosobranchia) and Corophium arenarium Crawford (Amphipoda) on sediment microalgal populations. II Quantitative effects. J Exp Mar Biol Ecol 118:43-53

Nowell AR, Jumars PA. (1987) Flumes: theoretical and experimental considerations for simulations of benthic environments. Oceanogr Mar Biol Annu Rev 25:91-112

Nowell ARM, Jumars PA (1984) Flow environments of aquatic benthos. Annu Rev Ecol Syst 15:303-328

Nowell ARM, Jumars PA, Eckman JE (1981) Effects of biological activity on the entranment of marine sediments. Mar Geol 42:133-153

Palmer JD, Round FE (1967) Persistent, vertical-migration rhythms in benthic microflora. VI. The tidal and diurnal nature of the rhythm in the diatom Hantzschia virgata. Biol Bull 132:44-55

Paterson DM (1989) Short-term changes in the erodibility of intertidal cohesive sediments related to the migratory behaviour of epipelic diatoms. Limnol Oceanogr 34: $223-234$

This article was submitted to the editor
Paterson DM. Crawford RM, Little C (1990) Sub-aerial exposure and changes in stability of intertidal estuarine sediments. Estuar Coast Shelf Sci 30:541-556

Potvin C (1993) ANOVA: experiments in controlled environments. In: Scheiner SM, Gurevitch J (eds) Design and analysis of ecological experiments. Chapman \& Hall, London, p 46-68

Raillard O, Le Hir P, Lazure P (1994) Transport de sédiments fins dans le bassin de Marennes-Oléron: mise en place d'un modèle mathématique. Houille Blanche 4:63-71

Reise K (1985) Tidal flat ecology. An experimental approach to species interactions. Springer-Verlag, Berlin

Rhoads DC, Boyer LF (1982) The effects of marine benthos on physical properties of sediments: a successional perspective. In: McCall PL, Tevesz MJS (eds) Animal-sediment relations: the biogenic alteration of sediments. Plenum Press, New York, p 3-52

Roman MR, Tenore KR (1978) Tidal resuspension in Buzzards Bay, Massachusetts. I. Seasonal changes in the resuspension of organic carbon and chlorophyll a. Estuar Coast Shelf Sci 6:37-46

Round FE (1979) Occurrence and rhythmic behaviour of Tropidoneis lepidoptera in the epipelon of Barnstable Harbor, Massachusetts, USA. Mar Biol 54:215-217

Sauriau PG (1987) Les mollusques non-cultivés du bassin de Marennes-Oléron: quantification et répartition géographique des stocks. Haliotis 16:527-541

Sauriau PG, Mouret V, Rincé JP (1989) Organisation trophique de la malacofaune benthique non cultivee du bassin ostréicole de Marennes-Oléron. Oceanol Acta 12: 193-204

Shaffer GP, Sullivan MJ (1988) Water column productivity attributable to displaced benthic diatoms in well-mixed shallow estuaries. J Phycol 24:132-140

Sokal RR, Rohlf FJ (1981) Biometry. WH Freeman and Co, New York

Varela M, Penas E (1985) Primary production of benthic microalgae in an intertidal sand flat of the Ria de Arosa, NW Spain. Mar Ecol Prog Ser 25:111-119

Velji MI, Albright LJ (1986) Microscopic enumeration of attached marine bacteria of seawater, marine sediment, fecal matter, and kelp blade samples following pyrophosphate and ultrasound treatments. Can J Microbiol 32: $121-126$

Velji MI, Albright LJ (1993) Improved sample preparation for enumeration of aggregated aquatic substrate bacteria In: Kemp PF, Sherr BF, Sherr EB, Cole JJ (eds) Aquatic microbial ecology. Lewis Publ, Boca Raton, p 139-142

Wainright SC (1990) Sediment-to-water fluxes of particulate material and microbes by resuspension and their contribution to the planktonic food web. Mar Ecol Prog Ser 62: $271-281$

Manuscript first received: December 16, 1996 Revised version accepted: March 14, 1997 